(c) American Dairy Science Association, 2006.

\title{
Enhanced Nutty Flavor Formation in Cheddar Cheese Made with a Malty Lactococcus lactis Adjunct Culture
}

\author{
M. E. Carunchia Whetstine, ${ }^{*}$ M. A. Drake, ${ }^{* 1}$ J. R. Broadbent, $†$ and D. McMahon† \\ *Department of Food Science, Southeast Dairy Foods Research Center, North Carolina State University, Raleigh 27695 \\ †Department of Nutrition and Food Sciences, Western Dairy Center, Utah State University, Logan 84322
}

\begin{abstract}
Nutty flavor in Cheddar cheese is desirable, and recent research demonstrated that 2- and 3-methyl butanal and 2-methyl propanal were primary sources of nutty flavors in Cheddar. Because malty strains of Lactococcus lactis (formerly Streptococcus lactis var. maltigenes) are characterized by the efficient production of these and other Strecker aldehydes during growth, this study investigated the influence of a malty $L$. lactis adjunct culture on nutty flavor development in Cheddar cheese. Cheeses made with different adjunct levels $(0$, $10^{4} \mathrm{cfu} / \mathrm{mL}$, and $10^{5} \mathrm{cfu} / \mathrm{mL}$ ) were ripened at 5 or $13^{\circ} \mathrm{C}$ and analyzed after $1 \mathrm{wk}, 4 \mathrm{mo}$, and 8 mo by a combination of instrumental and sensory methods to characterize nutty flavor development. Cheeses ripened at $13^{\circ} \mathrm{C}$ developed aged flavors (brothy, sulfur, and nutty flavors) more rapidly than cheeses held at $5^{\circ} \mathrm{C}$. Additionally, cheeses made with the adjunct culture showed more rapid and more intense nutty flavor development than control cheeses. Cheeses that had higher intensities of nutty flavors also had a higher concentration of 2/3-methyl butanal and 2-methyl propanal compared with control cheeses, which again confirmed that these compounds are a source of nutty flavor in Cheddar cheese. Results from this study provide a simple methodology for cheese manufacturers to obtain consistent nutty flavor in Cheddar cheese.
\end{abstract}

Key words: Strecker aldehyde, Cheddar cheese flavor, adjunct culture, Lactococcus lactis

\section{INTRODUCTION}

The flavor of Cheddar cheese is one of the most important attributes that affects consumer acceptance and marketing. However, there is not a single definition of Cheddar cheese flavor. Flavor can vary widely among Cheddars and is a function of many factors, including manufacturer, milk source, microflora, age, and fat con-

Received March 17, 2006.

Accepted April 18, 2006.

${ }^{1}$ Corresponding author: mdrake@unity.ncsu.edu tent. Although there is much variability in Cheddar flavor, aged Cheddar cheese is generally characterized by sulfur, brothy, and nutty flavors (Urbach, 1997; Drake et al., 2001). Aged cheeses are typically more expensive than younger Cheddars because they must be stored for long periods, and characteristic aged flavors in Cheddar cheese are desirable to some consumer segments (Young et al., 2004). It would therefore be economically advantageous if cheese manufacturers could accelerate ripening and consistently produce characteristic aged flavors in younger cheeses.

Avsar et al. (2004) recently determined that the Strecker aldehydes 2/3-methyl butanal and 2-methyl propanal, which are derived from valine, leucine, and isoleucine (Weenen and van der Ven, 2001), have central roles in the nutty flavor of Cheddar cheese. Nutty flavors are desirable, but they are generally only found in extremely aged Cheddar cheeses ( $>9 \mathrm{mo}$; Drake et al., 2001; Avsar et al., 2004). Following identification of the volatile compound sources of nutty flavor in Cheddar cheese, Avsar et al. (2004) proposed 3 methods to increase the amount of nutty flavor (concentration of 2/3-methyl butanal and 2-methyl propanal) in Cheddar cheese: 1) the use of starter bacteria capable of releasing branched-chain AA (precursors to the Strecker aldehydes), 2) additions of these AA into cheese milk or cheese slurry, 3) accelerating the conversion rate of these AA into aroma compounds. The present study utilized an adjunct culture that preferentially degrades the AA (via transamination and decarboxylation) that are responsible for forming the Strecker aldehydes 2/ 3-methyl butanal and 2-methyl propanal.

Certain strains of Lactococcus lactis (formerly called Streptococcus lactis var. maltigenes), for example, are known to impart a unique malty flavor to milk because they produce elevated levels of 3-methyl butanal (Jackson and Morgan, 1954; Tucker and Morgan, 1967). The objectives of this study were to determine whether addition of a malty L. lactis adjunct could promote nutty flavor development in Cheddar cheese. Cheddar cheese was made with different adjunct levels; then a combination of chemical and sensory methods was used to follow nutty flavor development and 2/3-methyl butanal and 
2-methyl propanal accumulation in the cheeses over an 8 -mo ripening period.

\section{MATERIALS AND METHODS}

\section{Bacterial Cultures}

The malty adjunct L. lactis ATCC 29146 was purchased from the American Type Culture Collection (Rockville, MD) and maintained at $-80^{\circ} \mathrm{C}$ in UHT skim milk (Gossner Foods Inc., Logan, UT) with $11 \%$ glycerol. Working cultures were prepared from frozen stocks by overnight incubation at $30^{\circ} \mathrm{C}$ in M17 medium (Difco, Detroit, MI) with $0.5 \%$ (wt/vol) lactose (M17-L). The cheese starter bacterium $L$. lactis 850 was obtained as a frozen cell concentrate from Chr. Hansen Laboratories Inc. (Milwaukee, WI) and added directly to cheese milk as directed by the supplier.

Cheese Manufacture. Cheddar cheese was manufactured on 3 separate occasions from $227-\mathrm{kg}$ lots of pasteurized milk that had been standardized to contain a protein:fat ratio of 0.83 . One day before each trial, a $2 \%$ inoculum of freshly prepared adjunct was made into $20 \mathrm{~mL}$ of UHT skim milk, incubated 6 to $8 \mathrm{~h}$ at $30^{\circ} \mathrm{C}$, then subcultured into $950 \mathrm{~mL}$ of UHT skim milk and incubated overnight (approximately $18 \mathrm{~h}$ ). The concentration of adjunct cells in the milk inoculum was determined by the spread plate method on M17-L agar.

On each day of cheese making, 3 separate vats of Cheddar were produced wherein 0 (control), 1 , or 10 $\mathrm{mL}$ of the adjunct culture was added to the cheese milk in conjunction with the L. lactis 850 starter (resulting in an average of $1.0 \times 10^{4} \pm 6.9 \times 10^{3} \mathrm{cfu} / \mathrm{mL}$ and $1.0 \times$ $10^{5} \pm 6.9 \times 10^{4} \mathrm{cfu} / \mathrm{mL}$ of adjunct). The level of starter inoculum ranged from 20 to $28 \mathrm{~g}$, depending on milk seasonal variation and the amount of added adjunct, to obtain a uniform rate of acid production and a setto-make time of approximately $4.5 \mathrm{~h}$. Inoculated cheese milk was ripened for $30 \mathrm{~min}$; then $27 \mathrm{~mL}$ of $\mathrm{CaCl}_{2}(34 \%$ solution, DSM Food Specialties, Menomonee Falls, WI) and $18 \mathrm{~mL}$ of double-strength chymosin (Maxiren, DSM Food Specialties) were added. The milk was allowed to set for $31 \mathrm{~min}$; then the coagulum was cut with 0.95 $\mathrm{cm}$ knives and allowed to heal for $5 \mathrm{~min}$. After $25 \mathrm{~min}$ of gentle agitation, the temperature of the curd and whey slurry was raised from 30 to $39^{\circ} \mathrm{C}$ over $35 \mathrm{~min}$; then, the whey was slowly drained $(\mathrm{pH}$ at pack was $6.39 \pm 0.05)$. The curd was trenched, cut into loaves, cheddared, and then milled ( $\mathrm{pH}$ at mill was $5.43 \pm 0.07$ ). Five minutes from start of milling, the curd was salted in 3 additions, 5 min apart, with $0.285 \%$ (wt/wt) flake salt (calculated from the original milk weight), then stirred until the salt had dissolved. Salted curd was packed into 9-kg rectangular stainless steel hoops, pressed overnight at ambient temperature, vacuum packaged; then, 1 block of each treatment (control, $10^{4}$ $\mathrm{cfu} / \mathrm{mL}$ of adjunct, and $10^{5} \mathrm{cfu} / \mathrm{mL}$ of adjunct) were stored at 5 or $13^{\circ} \mathrm{C}$. Samples for sensory and instrumental analysis were collected after $1 \mathrm{wk}, 4 \mathrm{mo}$, and $8 \mathrm{mo}$ of ripening.

\section{Proximate Analysis}

The $\mathrm{pH}$, moisture, fat, and salt content were determined for all cheeses prior to aging using standard methods. Cheese $\mathrm{pH}$ was measured on grated cheese using a Xerolyt combination electrode (model HA405, Mettler Toledo, Columbus, $\mathrm{OH}$ ) and an Accumet $\mathrm{pH}$ meter (model AR 25, Fisher Scientific, Pittsburgh, PA) after tempering to $23^{\circ} \mathrm{C}$. Fat content was determined using the Babcock method (method 15.8.A; American Public Health Association, 1992). Cheese moisture was determined gravimetrically by drying $2 \mathrm{~g}$ of cheese in a forced-air oven at $100^{\circ} \mathrm{C}$ for $24 \mathrm{~h}$ (method 33.2.5, 990.20; AOAC, 2000). Salt content was determined using the Volhard method (method 15.5.B; American Public Health Association, 1992).

\section{Sensory Evaluation of Cheeses}

At $1 \mathrm{wk}, 4 \mathrm{mo}$, and $8 \mathrm{mo}$, cheeses were sampled for sensory analysis. A sensory panel $(n=15)$ evaluated the cheeses using the flavor lexicon developed for Cheddar cheese (Drake et al., 2001). The definitions and references for the terms are provided in Table 1 . Cheese was presented in $2 \times 2 \mathrm{~cm}$ cubes in 60 -g lidded soufflé cups labeled with random 3-digit codes. Panelists were trained for $>75 \mathrm{~h}$ on flavor, aroma, and feeling factors using the Spectrum method (Meilgaard et al., 1999). The 15-point numerical Spectrum intensity scale was used to mark the panelists' responses. During evaluation, panelists had free access to water and unsalted crackers. Cheeses were evaluated in duplicate on separate occasions by each panelist.

\section{Dynamic Headspace Analysis Followed by Gas Chromatography/Mass Spectrometry}

Cheese blocks were thawed overnight and grated using a hand grater. Then $50 \mathrm{~g}$ of each cheese was grated, and $500 \mu \mathrm{L}$ of internal standard [10 $\mu \mathrm{L}$ of (E)-2-methyl2-butenal in $10 \mathrm{~mL}$ of methanol; $410 \mu \mathrm{L}$ of this added to $10 \mathrm{~mL}$ of methanol] was added to the grated cheese. The cheese was then kneaded and thoroughly mixed to evenly distribute the internal standard. This reformed cheese sample was refrigerated at $4^{\circ} \mathrm{C}$ for overnight to equilibrate and then frozen at $-80^{\circ} \mathrm{C}$ for at least $24 \mathrm{~h}$. Cheese was then grated again, and $10 \mathrm{~g}$ of cheese was added to $20 \mathrm{~g}$ of water and thoroughly mixed using a 


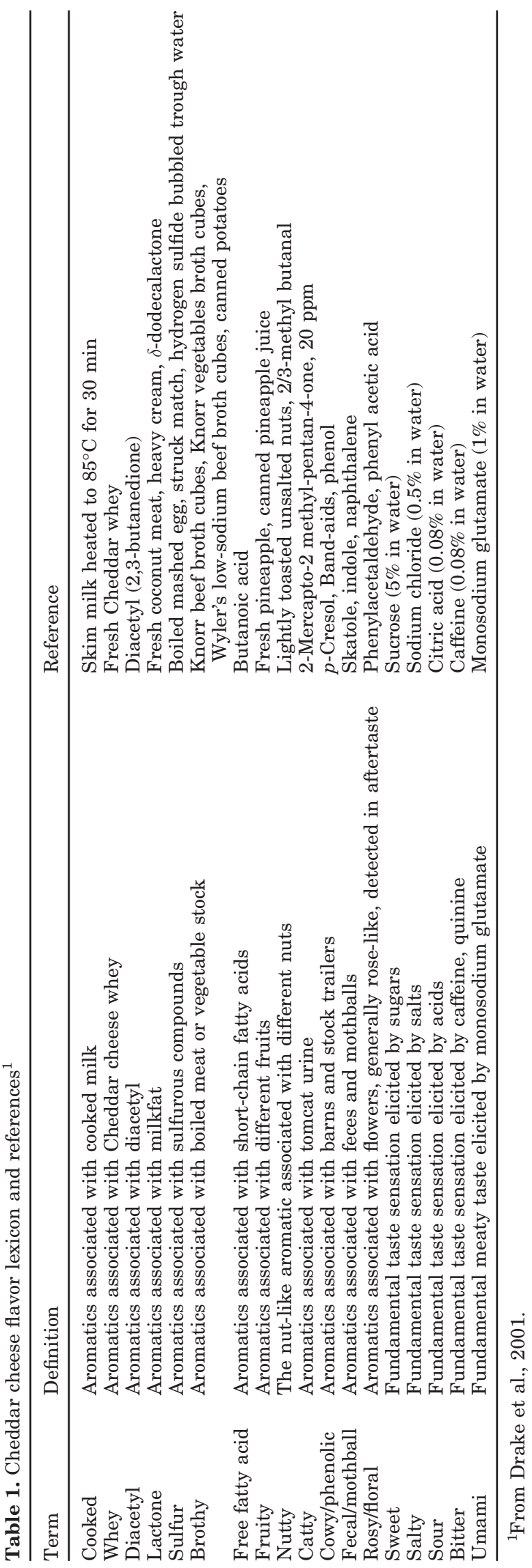

hand homogenizer. Five grams of cheese slurry was loaded into a needle sparger $25-\mathrm{mL}$ purge-and-trap vial (Vernon, British Columbia, Canada) along with $2 \mathrm{~g}$ of salt. The vial was equilibrated at room temperature for 30 min and then placed on a CDS Purge and Trap CDS 6000 (Oxford, PA) and purged with nitrogen at $40 \mathrm{~mL} /$ min. The initial purge volume was $800 \mathrm{~mL}$ (32 min). Concentrated volatile compounds were desorbed from the trap and then transferred by a heated transfer line to the gas chromatograph and desorbed onto a nonpolar DB-5MS column (30 m length $\times 0.25 \mathrm{~mm}$ inside diameter $\times 0.25 \mu \mathrm{m} \mathrm{d}$; J \& W Scientific, Folsom, CA) on a HP5890 Series II GC/HP 5972 mass selective detector (Hewlett-Packard Co., Palo Alto, CA) The oven temperature was programmed at -20 to $60^{\circ} \mathrm{C}$ at a rate of $4^{\circ} \mathrm{C} /$ min with a 6-min hold at $-20^{\circ} \mathrm{C}$, and then 60 to $220^{\circ} \mathrm{C}$ at a rate of $6^{\circ} \mathrm{C} / \mathrm{min}$ with a final hold of $5 \mathrm{~min}$, respectively. Mass selective detector conditions were as follows: capillary direct interface temperature, $280^{\circ} \mathrm{C}$; ionization energy, $70 \mathrm{eV}$; mass range, 33-330 amu; electron multiplier voltage (Atune $+200 \mathrm{~V})$; scan rate, 5 scans/s. Triplicate analyses were performed on each sample. Based on mass spectrometry results, concentrations of 2/3methyl butanal and 2-methyl propanal were calculated.

For positive identifications, retention indices and mass spectra were compared with those of authentic standard compounds analyzed under identical conditions. Tentative identifications were based on comparing mass spectra of unknown compounds with those in the National Institute of Standards and Technology (1992) mass spectral database or on matching the retention index values against those of authentic standards. For the calculation of retention indices, an n-alkane series was used (Van den Dool and Kratz, 1963).

\section{Quantification of Odorants}

Response factors of 2/3-methyl butanal and 2-methyl propanal were calculated by direct addition of known amounts of standards to odor-free water prior to dynamic headspace analysis and gas chromatography/ mass spectrometry. Response factors for compounds were determined using a 5-point standard curve $\left(R^{2}>\right.$ 0.95) on a DB-5 column using gas chromatography/ mass spectrometry. Using these response factors, the selected compounds were quantified using the response factor and the area ratio of compound to the internal standard [(E)-2-methyl-2-butanal]. All standards were obtained from Aldrich Chemical Company (St. Louis, MO).

\section{Statistical Analysis}

Data were analyzed for main effects (culture, temperature) and interactions at each timepoint by ANOVA 
Table 2. Proximate composition of cheeses ${ }^{1}$

\begin{tabular}{lllc}
\hline & & \multicolumn{2}{c}{ Added adjunct culture } \\
\cline { 3 - 4 } Component & Control & $\begin{array}{l}10^{4} \\
\text { cfu/mL }\end{array}$ & $\begin{array}{l}10^{5} \\
\text { cfu/mL }\end{array}$ \\
\hline Moisture, \% & $37.6^{\mathrm{a}}$ & $36.6^{\mathrm{a}}$ & $36.7^{\mathrm{a}}$ \\
Butterfat, \% & $33.4^{\mathrm{a}}$ & $33.5^{\mathrm{a}}$ & $33.6^{\mathrm{a}}$ \\
Fat dry basis, \% & $53.6^{\mathrm{a}}$ & $52.9^{\mathrm{a}}$ & $54.1^{\mathrm{a}}$ \\
pH & $5.11^{\mathrm{a}}$ & $5.12^{\mathrm{a}}$ & $5.14^{\mathrm{a}}$ \\
Salt, \% & $1.65^{\mathrm{a}}$ & $1.72^{\mathrm{a}}$ & $1.64^{\mathrm{a}}$ \\
\hline
\end{tabular}

${ }^{\mathrm{a}}$ Means in a row followed by different letters are different $(P<$ 0.05).

${ }^{1}$ Means are the results from duplicate analyses of triplicate batches of cheese.

with means separation (least squares means; SAS, version 8.2, SAS Institute, Cary, NC).

\section{RESULTS AND DISCUSSION}

\section{Cheese Composition}

Composition of the cheeses was similar $(P>0.05)$ as shown in Table 2. Therefore, any differences observed in flavor and texture among the cheeses can be attributed to addition of the adjunct culture or storage temperature.

\section{Sensory Analysis and Flavor Formation}

Table 3 summarizes the sensory profiles of cheeses after $1 \mathrm{wk}$ of aging. Although the flavor profiles of Cheddar cheese can vary widely, aged Cheddar cheese is generally characterized by brothy, sulfur, and nutty flavors, whereas young Cheddars are characterized by young/undeveloped flavors such as cooked, whey, diace- tyl, and milkfat/lactone (Drake et al., 2001). Even after $1 \mathrm{wk}$, cheeses that had been ripened at $13^{\circ} \mathrm{C}$ generally had lower intensities of these young/undeveloped flavors (especially whey, diacetyl, and milkfat/lactone flavors) and higher intensities of aged/developed flavors (especially sulfur and nutty flavors) than the cheeses developed at $5^{\circ} \mathrm{C}$.

After 4 mo, there were no differences in young/undeveloped flavors in the cheeses with the exception of whey flavor (Table 4). Whey flavor was present in higher intensities in cheeses ripened at $5^{\circ} \mathrm{C}$ compared with cheeses ripened at $13^{\circ} \mathrm{C}$. This is a young/undeveloped flavor. It was expected that lower intensities of young/ undeveloped flavors would be present in the cheeses ripened at higher temperatures because increasing the temperature accelerates development of aged flavors via increased enzymatic activity and consequent proteolysis (Cromie et al., 1987; Folkertsma et al., 1996). There were some differences in the intensities of aged developed flavors in the cheeses ripened at the different temperatures, but there were no clear trends after 4 mo of aging. Nutty flavor developed more intensely in the cheeses ripened at $13^{\circ} \mathrm{C}$ and in the cheeses that had higher levels of adjunct added (Table 4).

The intensities of young/undeveloped flavors (cooked/ milk, whey, diacetyl, milkfat) decreased significantly $(P<0.05)$ in all cheeses after 8 mo of aging (Table 5$)$. Whey flavor intensities were lower in the cheeses aged at $13^{\circ} \mathrm{C}$, following the trends that were observed after 4 mo of aging. Although there were no clear trends on aged/developed flavor development at $1 \mathrm{wk}$ or $4 \mathrm{mo}$, ripening trends were evident after 8 mo. Cheeses aged at $13^{\circ} \mathrm{C}$ had more intense sulfur and brothy flavors $(P$ $<0.05$ ) than cheeses ripened at $5^{\circ} \mathrm{C}$. Cheeses ripened

Table 3. Sensory analysis ${ }^{1}$ of 1 -wk-old cheeses made without (control) or with $10^{4}$ or $10^{5} \mathrm{cfu} / \mathrm{mL}$ of adjunct culture and aged at either 5 or $13^{\circ} \mathrm{C}$

\begin{tabular}{|c|c|c|c|c|c|c|}
\hline Attribute & Control & $\begin{array}{c}\text { Adjunct } \\
\left(10^{4} \mathrm{cfu} / \mathrm{mL}\right)\end{array}$ & $\begin{array}{c}\text { Adjunct } \\
\left(10^{5} \mathrm{cfu} / \mathrm{mL}\right)\end{array}$ & Control & $\begin{array}{c}\text { Adjunct } \\
\left(10^{4} \mathrm{cfu} / \mathrm{mL}\right)\end{array}$ & $\begin{array}{c}\text { Adjunct } \\
\left(10^{5} \mathrm{cfu} / \mathrm{mL}\right)\end{array}$ \\
\hline & \multicolumn{3}{|c|}{$\left(\right.$ Aged at $\left.5^{\circ} \mathrm{C}\right)$} & \multicolumn{3}{|c|}{ - $\left(\right.$ Aged at $\left.13^{\circ} \mathrm{C}\right)$} \\
\hline Cooked & $3.06^{\mathrm{a}}$ & $3.07^{\mathrm{a}}$ & $3.10^{\mathrm{a}}$ & $2.97^{\mathrm{ab}}$ & $2.95^{\mathrm{ab}}$ & $2.72^{\mathrm{b}}$ \\
\hline Whey & $2.73^{\mathrm{a}}$ & $2.88^{\mathrm{a}}$ & $2.86^{\mathrm{a}}$ & $2.69^{\mathrm{ab}}$ & $2.58^{\mathrm{ab}}$ & $2.36^{\mathrm{b}}$ \\
\hline Diacetyl & $0.52^{\mathrm{a}}$ & $0.67^{\mathrm{a}}$ & $0.51^{\mathrm{a}}$ & $\mathrm{ND}^{2}$ & $0.56^{\mathrm{a}}$ & ND \\
\hline Milkfat/lactone & $2.92^{\mathrm{ab}}$ & $3.03^{\mathrm{a}}$ & $2.91^{\mathrm{ab}}$ & $2.72^{\mathrm{b}}$ & $2.69^{b}$ & $2.23^{\mathrm{c}}$ \\
\hline Sulfur & ND & ND & ND & $0.61^{\mathrm{a}}$ & $0.51^{\mathrm{a}}$ & $0.69^{\mathrm{a}}$ \\
\hline Brothy & $0.81^{b}$ & $0.77^{\mathrm{b}}$ & $0.87^{\mathrm{b}}$ & $1.08^{\mathrm{ab}}$ & $1.09^{\mathrm{ab}}$ & $1.21^{\mathrm{a}}$ \\
\hline Nutty & ND & ND & $0.68^{\mathrm{ab}}$ & $0.53^{\mathrm{b}}$ & $0.56^{\mathrm{ab}}$ & $0.85^{\mathrm{a}}$ \\
\hline Sour & $3.42^{\mathrm{ab}}$ & $3.46^{\mathrm{ab}}$ & $3.29^{\mathrm{b}}$ & $3.56^{\mathrm{a}}$ & $3.47^{\mathrm{ab}}$ & $3.45^{\mathrm{ab}}$ \\
\hline Sweet & $1.85^{\mathrm{a}}$ & $1.92^{\mathrm{a}}$ & $1.97^{\mathrm{a}}$ & $1.96^{\mathrm{a}}$ & $1.98^{\mathrm{a}}$ & $1.91^{\mathrm{a}}$ \\
\hline Salty & $3.66^{\mathrm{a}}$ & $3.59^{\mathrm{a}}$ & $3.58^{\mathrm{a}}$ & $3.61^{\mathrm{a}}$ & $3.63^{\mathrm{a}}$ & $3.36^{\mathrm{b}}$ \\
\hline Umami & $1.27^{\mathrm{b}}$ & $1.22^{\mathrm{b}}$ & $1.36^{\mathrm{ab}}$ & $1.57^{\mathrm{ab}}$ & $1.64^{\mathrm{a}}$ & $1.20^{\mathrm{b}}$ \\
\hline
\end{tabular}

\footnotetext{
${ }^{\mathrm{a}, \mathrm{b}}$ Means in a row followed by different letters are different $(P<0.05)$.

${ }^{1}$ Intensities are scored on the 15 -point Spectrum universal scale where $0=$ none and $15=$ very high.

${ }^{2}$ The attributes fruity, free fatty acid, and catty and bitter tastes were not detected in cheeses. ND = attribute not detected in cheeses indicated.
} 
Table 4. Sensory analysis ${ }^{1}$ of 4-mo-old cheeses made without (control) or with $10^{4}$ or $10^{5} \mathrm{cfu} / \mathrm{mL}$ of adjunct culture and aged at either 5 or $13^{\circ} \mathrm{C}$

\begin{tabular}{|c|c|c|c|c|c|c|}
\hline Attribute & Control & $\begin{array}{c}\text { Adjunct } \\
\left(10^{4} \mathrm{cfu} / \mathrm{mL}\right)\end{array}$ & $\begin{array}{c}\text { Adjunct } \\
\left(10^{5} \mathrm{cfu} / \mathrm{mL}\right)\end{array}$ & Control & $\begin{array}{c}\text { Adjunct } \\
\left(10^{4} \mathrm{cfu} / \mathrm{mL}\right)\end{array}$ & $\begin{array}{c}\text { Adjunct } \\
\left(10^{5} \mathrm{cfu} / \mathrm{mL}\right)\end{array}$ \\
\hline & \multicolumn{3}{|c|}{$\longrightarrow\left(\right.$ Aged at $\left.5^{\circ} \mathrm{C}\right)$} & \multicolumn{3}{|c|}{$-\left(\right.$ Aged at $\left.13^{\circ} \mathrm{C}\right)$} \\
\hline Cooked & $2.67^{\mathrm{a}}$ & $2.69^{\mathrm{a}}$ & $2.65^{\mathrm{a}}$ & $2.65^{\mathrm{a}}$ & $2.75^{\mathrm{a}}$ & $2.75^{\mathrm{a}}$ \\
\hline Whey & $2.31^{\mathrm{a}}$ & $2.41^{\mathrm{a}}$ & $2.18^{\mathrm{ab}}$ & $1.97^{\mathrm{b}}$ & $2.31^{\mathrm{a}}$ & $1.48^{\mathrm{c}}$ \\
\hline Milkfat/lactone & $2.71^{\mathrm{a}}$ & $2.73^{\mathrm{a}}$ & $2.73^{\mathrm{a}}$ & $2.58^{\mathrm{a}}$ & $2.70^{\mathrm{a}}$ & $2.67^{\mathrm{a}}$ \\
\hline Sulfur & $1.15^{\mathrm{b}}$ & $1.10^{\mathrm{b}}$ & $1.11^{\mathrm{b}}$ & $1.47^{\mathrm{a}}$ & $1.26^{\mathrm{ab}}$ & $1.51^{\mathrm{a}}$ \\
\hline Brothy & $1.99^{\mathrm{bc}}$ & $1.74^{\mathrm{c}}$ & $1.95^{\mathrm{bc}}$ & $2.20^{\mathrm{ab}}$ & $2.13^{\mathrm{ab}}$ & $2.25^{\mathrm{a}}$ \\
\hline Nutty & $\mathrm{ND}^{2}$ & $0.52^{\mathrm{c}}$ & $0.79^{\mathrm{b}}$ & $0.75^{\mathrm{bc}}$ & $0.70^{\mathrm{bc}}$ & $1.51^{\mathrm{a}}$ \\
\hline Sour & $3.48^{\mathrm{a}}$ & $3.35^{\mathrm{ab}}$ & $3.23^{\mathrm{b}}$ & $3.41^{\mathrm{ab}}$ & $3.40^{\mathrm{ab}}$ & $3.43^{\mathrm{ab}}$ \\
\hline Sweet & $2.00^{\mathrm{c}}$ & $2.06^{\mathrm{c}}$ & $2.31^{\mathrm{a}}$ & $2.09^{\mathrm{bc}}$ & $2.14^{\mathrm{abc}}$ & $2.28^{\mathrm{ab}}$ \\
\hline Salty & $3.55^{\mathrm{a}}$ & $3.54^{\mathrm{a}}$ & $3.65^{\mathrm{a}}$ & $3.71^{\mathrm{a}}$ & $3.56^{\mathrm{a}}$ & $3.69^{\mathrm{a}}$ \\
\hline Umami & $1.84^{\mathrm{a}}$ & $1.92^{\mathrm{a}}$ & $1.79^{\mathrm{a}}$ & $1.96^{\mathrm{a}}$ & $1.97^{\mathrm{a}}$ & $2.01^{\mathrm{a}}$ \\
\hline
\end{tabular}

${ }^{\mathrm{a}-\mathrm{c}}$ Means in a row followed by different letters are different $(P<0.05)$.

${ }^{1}$ Intensities are scored on the 15 -point Spectrum universal scale where $0=$ none and $15=$ very high.

${ }^{2}$ The attributes fruity, free fatty acid, and catty and bitter tastes were not detected in any cheeses. ND = attribute not detected in cheeses indicated.

at $13^{\circ} \mathrm{C}$ and with increased concentrations of adjunct added had significantly $(P<0.05)$ higher nutty flavor intensity (Table 5).

As a whole, sensory results indicated that cheeses ripened at $13^{\circ} \mathrm{C}$ developed aged flavors more quickly than the cheeses ripened at $5^{\circ} \mathrm{C}$, and adjunct addition accelerated the development of aged flavors $(P<0.05)$. The development of sulfur and brothy flavors were strongly correlated $(r=0.98)$, and the development of nutty flavor was also correlated to development of these other aged flavors $(r=0.75$ for brothy; $r=0.79$ for sulfur). Overall, these findings are in agreement with other reports that noted nutty flavor is not typically found in young Cheddar cheeses (Drake et al., 2001; Avsar et al., 2004; Drake et al., 2005).

There were no statistically significant interactions $(P$ $<0.05$ ) between ripening temperature and level of added adjunct for any attribute except nutty flavor.
The cheeses that had the adjunct culture added had significantly higher concentrations of nutty flavor, and samples that were ripened at $13^{\circ} \mathrm{C}$ had higher intensities of nutty flavor than the cheeses ripened at $5^{\circ} \mathrm{C}$ (Tables $3,4,5)$. Nutty flavor is not typically found in young $(<4 \mathrm{mo})$ Cheddars. However, in the cheeses aged for $1 \mathrm{wk}$, nutty flavor was found at low levels (around sensory threshold) in the cheeses in which $10^{5} \mathrm{cfu} / \mathrm{mL}$ of the adjunct blend was added at both 5 and $13^{\circ} \mathrm{C}$ storage.

It is interesting to note that Avsar et al. (2004) demonstrated that when young Cheddars were spiked with 2/3-methyl butanal and 2-methyl propanal, panelists described the flavor as nutty/malty. When these same compounds were spiked into aged Cheddar cheeses, the panelists simply described the cheeses as nutty. Similar results were found in this study. Panelists described the 1-wk-old cheeses as nutty/malty, whereas the 4and 8-mo cheeses were only described as nutty. These

Table 5. Sensory analysis ${ }^{1}$ of 8-mo-old cheeses made without (control) or with $10^{4}$ or $10^{5} \mathrm{cfu} / \mathrm{mL}$ of adjunct culture and aged at either 5 or $13^{\circ} \mathrm{C}$

\begin{tabular}{|c|c|c|c|c|c|c|}
\hline Attribute & Control & $\begin{array}{c}\text { Adjunct } \\
\left(10^{4} \mathrm{cfu} / \mathrm{mL}\right)\end{array}$ & $\begin{array}{c}\text { Adjunct } \\
\left(10^{5} \mathrm{cfu} / \mathrm{mL}\right)\end{array}$ & Control & $\begin{array}{c}\text { Adjunct } \\
\left(10^{4} \mathrm{cfu} / \mathrm{mL}\right)\end{array}$ & $\begin{array}{c}\text { Adjunct } \\
\left(10^{5} \mathrm{cfu} / \mathrm{mL}\right)\end{array}$ \\
\hline & \multicolumn{3}{|c|}{$\longrightarrow\left(\right.$ Aged at $\left.5^{\circ} \mathrm{C}\right)$} & \multicolumn{3}{|c|}{ - (Aged at $13^{\circ} \mathrm{C}$ ) } \\
\hline Cooked & $2.42^{\mathrm{abc}}$ & $2.60^{\mathrm{a}}$ & $2.52^{\mathrm{ab}}$ & $2.21^{\mathrm{c}}$ & $2.38^{\mathrm{abc}}$ & $2.26^{\mathrm{bc}}$ \\
\hline Whey & $1.27^{\mathrm{a}}$ & $1.33^{\mathrm{a}}$ & $1.26^{\mathrm{a}}$ & $0.50^{\mathrm{b}}$ & $0.61^{\mathrm{b}}$ & $0.72^{\mathrm{b}}$ \\
\hline Milkfat/lactone & $2.51^{\mathrm{ab}}$ & $2.55^{\mathrm{a}}$ & $2.43^{\mathrm{ab}}$ & $2.25^{\mathrm{b}}$ & $2.39^{\mathrm{ab}}$ & $2.33^{\mathrm{ab}}$ \\
\hline Sulfur & $1.52^{\mathrm{c}}$ & $1.66^{\mathrm{c}}$ & $2.63^{\mathrm{a}}$ & $2.01^{\mathrm{ab}}$ & $2.07^{\mathrm{ab}}$ & $2.17^{\mathrm{a}}$ \\
\hline Brothy & $1.93^{\mathrm{b}}$ & $2.01^{b}$ & $1.97^{\mathrm{b}}$ & $2.59^{\mathrm{a}}$ & $2.58^{\mathrm{a}}$ & $2.84^{\mathrm{a}}$ \\
\hline Nutty & $0.82^{\mathrm{c}}$ & $0.73^{\mathrm{c}}$ & $1.51^{\mathrm{ab}}$ & $1.26^{\mathrm{b}}$ & $1.64^{\mathrm{a}}$ & $1.87^{\mathrm{a}}$ \\
\hline Sour & $3.23^{\mathrm{bc}}$ & $3.07^{\mathrm{c}}$ & $3.19^{\mathrm{bc}}$ & $3.51^{\mathrm{a}}$ & $3.40^{\mathrm{ab}}$ & $3.51^{\mathrm{a}}$ \\
\hline Sweet & $2.17^{\mathrm{a}}$ & $2.31^{\mathrm{a}}$ & $2.47^{\mathrm{a}}$ & $2.36^{\mathrm{a}}$ & $2.43^{\mathrm{a}}$ & $2.38^{\mathrm{a}}$ \\
\hline Salty & $3.59^{\mathrm{ab}}$ & $3.57^{\mathrm{ab}}$ & $3.53^{\mathrm{b}}$ & $3.74^{\mathrm{ab}}$ & $3.72^{\mathrm{ab}}$ & $3.79^{\mathrm{a}}$ \\
\hline Umami & $1.91^{\mathrm{bc}}$ & $1.83^{\mathrm{c}}$ & $2.00^{\mathrm{bc}}$ & $2.22^{\mathrm{ab}}$ & $2.20^{\mathrm{ab}}$ & $2.31^{\mathrm{a}}$ \\
\hline
\end{tabular}

${ }^{\mathrm{a}-\mathrm{c}}$ Means in a row followed by different letters are different $(P<0.05)$.

${ }^{1}$ Intensities are scored on the 15-point Spectrum universal scale where $0=$ none and $15=$ very high. 
findings support the hypothesis that when levels of 2/ 3 -methyl butanal and 2-methyl propanal are present above sensory threshold, but other aged flavors have not yet developed, these compounds are perceived as nutty/malty (Avsar et al., 2004). However, once the cheeses have aged sufficiently and other aged flavors are present, cheeses with elevated levels of 2/3-methyl butanal and 2-methyl propanal are perceived as nutty.

The formation of 2-methyl butanal, 3-methyl butanal, and 2-methyl propanal is a result of Strecker degradation of branched-chain AA Ile, Leu, and Val, respectively (Urbach, 1995; Yvon et al., 1998; Rijnen et al., 1999). In Cheddar cheese, the breakdown of intact caseins into peptides and free AA is a complex process that involves endogenous milk enzymes, rennet, and microbial proteinases and peptidases (Stepaniak, 2004). Moreover, conversion of liberated amino acids into Strecker aldehydes and other flavor and aroma compounds is likely the rate-limiting step in the development of aged flavors (Tanous et al., 2002). As a result, nutty flavor is rarely found in young cheese. In lactococci, production of Strecker aldehydes from free AA involves sequential transamination and decarboxylation reactions (Yvon and Rijnen, 2001) catalyzed by metabolically active, intact cells or perhaps by starter enzymes in the cheese matrix (Bourdat-Deschamps et al., 2004; Smit et al., 2005). Lactococcal viability during cheese maturation is a strain-specific and highly variable trait (Fryer, 1969) and was not monitored in this study because we could not readily distinguish between starter and adjunct populations. Nonetheless, the adjunct culture used in this study, L. lactis ATCC 29146, is a member of the maltigenes, or malty biogroup of lactococci, which is characterized by the ability to produce increased concentrations of 2/3-methyl butanal and 2-methyl propanal in broth or skim milk (Jackson and Morgan, 1954; Tucker and Morgan, 1967; Sheldon et al., 1971) compared with other lactic acid strains. Because these aldehydes are primary determinants of nutty flavor in aged Cheddar cheese (Avsar et al., 2004), cheeses made with $L$. lactis ATCC 29146 were expected to contain higher levels of 2/3-methyl butanal and 2methyl propanal and to show more rapid and intense nutty flavor development. As is shown in Table 6, this outcome was indeed observed.

Although concentrations of 2/3-methyl butanal and 2 -methyl propanal were higher in the cheeses that had higher amounts of the adjunct added for both ripening temperatures $(P<0.05)$ (Table 6$)$, temperature effects were also observed. Cheeses ripened at $13^{\circ} \mathrm{C}$ had higher concentrations of 2/3-methyl butanal and 2-methyl propanal than samples ripened at $5^{\circ} \mathrm{C}(P<0.05)$. The cheeses ripened at $5^{\circ} \mathrm{C}$ had levels of 2-methyl propanal above threshold, but 2/3-methyl butanal concentrations
Table 6. Concentrations of 2/3-methyl butanal and 2-methyl propanal in cheeses ${ }^{1}$

\begin{tabular}{|c|c|c|c|}
\hline \multirow[b]{2}{*}{ Item } & & \multicolumn{2}{|c|}{ Compound } \\
\hline & & $\begin{array}{l}\text { 2-methyl } \\
\text { propanal }\end{array}$ & $\begin{array}{l}2 / 3 \text {-methyl } \\
\text { butanal }\end{array}$ \\
\hline \multirow{2}{*}{\multicolumn{2}{|c|}{$\begin{array}{l}\text { Retention index on DB-5MS column } \\
\text { Reported threshold, } \mathrm{ppb}^{2}\end{array}$}} & 600 & 686 \\
\hline & & 3.5 & 1.5 \\
\hline \multicolumn{2}{|l|}{ Sample } & \multicolumn{2}{|c|}{ Concentration, ppb } \\
\hline \multirow[t]{3}{*}{ Control, aged at $5^{\circ} \mathrm{C}$} & $1 \mathrm{wk}$ & $\mathrm{ND}^{3}$ & ND \\
\hline & $4 \mathrm{mo}$ & ND & ND \\
\hline & $8 \mathrm{mo}$ & $9.0^{\mathrm{c}}$ & ND \\
\hline \multirow[t]{3}{*}{ Adjunct $\left(10^{4} \mathrm{cfu} / \mathrm{mL}\right)$, aged at $5^{\circ} \mathrm{C}$} & $1 \mathrm{wk}$ & ND & ND \\
\hline & $4 \mathrm{mo}$ & $2.8^{\mathrm{c}}$ & $0.13^{\mathrm{c}}$ \\
\hline & $8 \mathrm{mo}$ & $22.9^{\mathrm{b}}$ & $1.08^{\mathrm{b}}$ \\
\hline \multirow{3}{*}{ Adjunct $\left(10^{5} \mathrm{cfu} / \mathrm{mL}\right)$, aged at $5^{\circ} \mathrm{C}$} & $1 \mathrm{wk}$ & ND & ND \\
\hline & $4 \mathrm{mo}$ & $5.4^{\mathrm{b}}$ & $0.25^{\mathrm{c}}$ \\
\hline & $8 \mathrm{mo}$ & $19.9^{b}$ & $0.94^{\mathrm{b}}$ \\
\hline \multirow[t]{3}{*}{ Control, aged at $13^{\circ} \mathrm{C}$} & $1 \mathrm{wk}$ & ND & ND \\
\hline & $4 \mathrm{mo}$ & ND & ND \\
\hline & $8 \mathrm{mo}$ & $9.8^{\mathrm{c}}$ & $0.46^{\mathrm{c}}$ \\
\hline \multirow[t]{3}{*}{ Adjunct $\left(10^{4} \mathrm{cfu} / \mathrm{mL}\right)$, aged at $13^{\circ} \mathrm{C}$} & $1 \mathrm{wk}$ & $2.1^{\mathrm{c}}$ & ND \\
\hline & $4 \mathrm{mo}$ & $13.5^{\mathrm{b}}$ & $0.64^{\mathrm{b}}$ \\
\hline & $8 \mathrm{mo}$ & $47.98^{\mathrm{a}}$ & $2.26^{\mathrm{a}}$ \\
\hline \multirow{3}{*}{ Adjunct $\left(10^{5} \mathrm{cfu} / \mathrm{mL}\right)$, aged at $13^{\circ} \mathrm{C}$} & $1 \mathrm{wk}$ & ND & $\mathrm{ND}$ \\
\hline & $4 \mathrm{mo}$ & $14.8^{\mathrm{b}}$ & $0.70^{\mathrm{b}}$ \\
\hline & $8 \mathrm{mo}$ & $50.7^{\mathrm{a}}$ & $2.4^{\mathrm{a}}$ \\
\hline
\end{tabular}

${ }^{\mathrm{a}-\mathrm{c}}$ Means in a column followed by different letters are different $(P$ $<0.05)$.

${ }^{1}$ Means are the values of 3 replications from triplicate batches of cheese of each treatment.

${ }^{2}$ Thresholds reported orthonasally in water by Rychlik et al., 1998.

${ }^{3} \mathrm{ND}=$ Not detected.

were not above the sensory threshold. In the cheeses ripened at $13^{\circ} \mathrm{C}$, the addition of adjunct (at both levels) increased the concentration of 2/3-methyl butanal and 2 -methyl propanal above the sensory threshold for these compounds (Table 6). These observations were not surprising because adjunct addition and increased ripening temperature would each be expected to increase the rate of enzymatic activity in the cheese (Cromie et al., 1987; Folkertsma et al., 1996), leading to an increased production of 2-methyl propanal and 2/3methyl butanal.

There were no statistical differences in the concentrations of 2-methyl propanal and 2/3-methyl butanal in the cheeses that had the adjuncts added after $8 \mathrm{mo}$, even though there were differences in the nutty flavor intensity for the cheeses with both levels of adjuncts aged at $5^{\circ} \mathrm{C}$ (Tables 5 and 6 ). Perhaps the presence of other aged flavors influenced the perception of nutty flavor intensity. In the 8-mo cheeses aged at $5^{\circ} \mathrm{C}$, the sulfur flavor intensity was higher $(P<0.05)$ in the sample with $10^{5} \mathrm{cfu} / \mathrm{mL}$ added than in the $104 \mathrm{cfu} / \mathrm{mL}$ of adjunct added. The presence of other aged flavors, such as sulfur, may enhance the intensity of nutty flavor.

Nutty flavor also developed in the control cheeses during aging. In the 8-mo control cheeses, which had 
very low intensities of nutty flavor, 2-methyl propanal was present above sensory threshold (Rychlik et al., 1998), but 2/3-methyl butanal were not. Though 8-mo control cheeses had nutty flavor and low levels of 2methyl propanal and 2/3-methyl butanal, it is important to note that concentrations of 2/3-methyl butanal and 2 -methyl propanal were significantly $(P<0.05)$ higher in cheeses that contained adjunct as compared with the control cheeses. As a consequence, nutty flavor appeared earlier and was significantly $(P<0.05)$ more intense in cheeses made with the malty adjunct.

Avsar et al. (2004) found that 2-methyl propanal was present in higher concentrations in nutty Cheddar cheeses than 2/3-methyl butanal. They hypothesized that this compound might play a more crucial role in nutty flavor than 2/3-methyl butanal. Similar trends were observed in this study (Table 6). Although the aroma thresholds of these compounds are similar to each other, 2-methyl propanal was found in 10-fold higher concentrations than 2/3-methyl butanal in nutty Cheddar cheeses (Table 6; Avsar et al., 2004). One can conclude that this compound plays a stronger role in nutty flavor than 2/3-methyl butanal. These Strecker aldehydes were present in lower concentrations in the current study than reported by Avsar et al. (2004) in nutty Cheddars. In that study, however, the nutty Cheddars were all over 1 yr old. In this study, concentrations of 2/3-methyl butanal and 2-methyl propanal increased with time, and after $1+$ year of aging, one can assume that the concentrations of these compounds may be similar to those found by Avsar et al. (2004).

\section{CONCLUSIONS}

Adding L. lactis ATCC 29146 at the rate of $10^{4}$ or $10^{5}$ $\mathrm{cfu} / \mathrm{mL}$ of milk as an adjunct culture during manufacture of Cheddar cheese resulted in an increase in nutty flavor perception in the cheese. Cheeses ripened at $13^{\circ} \mathrm{C}$ developed aged flavors (including nutty) more rapidly than cheeses ripened at $5^{\circ} \mathrm{C}$. Panelists described the 1 wk-old cheeses as nutty/malty, whereas the 4- and 8mo cheeses were only described as nutty. The concentrations of 2/3-methyl butanal and 2-methyl propanal increased during aging and were higher in the cheeses with the adjunct added and in the cheeses ripened at $13^{\circ} \mathrm{C}$. This study demonstrates the advantages of linking descriptive sensory analysis, flavor chemistry, and starter culture biochemistry to control cheese flavor. These results allow cheese manufacturers the opportunity to optimize the cheese-making procedure to produce a consistent nutty flavored Cheddar cheese.

\section{ACKNOWLEDGMENTS}

Funding provided by Dairy Management Inc. (Rosemont, IL) and the California Dairy Research Founda- tion (Davis, CA). This is Manuscript No. FSR07-02 of the Department of Food Science, North Carolina State University. The use of trade names in the publication does not imply endorsement by these organizations or criticism of ones not mentioned.

\section{REFERENCES}

American Public Health Association. 1992. Standard Methods for the Examination of Dairy Products. 16th ed. R. T. Marshall, ed. Am. Publ. Health Assoc. Inc., Washington, DC.

Association of Official Analytical Chemists. 2000. Official Methods of Analysis. 17th ed. AOAC, Gaithersburg, MD.

Avsar, Y. K., Y. Karagul-Yuceer, M. A. Drake, T. K. Singh, Y. Yoon, and K. R. Cadwallader. 2004. Characterization of nutty flavor in Cheddar cheese. J. Dairy Sci. 87:1999-2010.

Bourdat-Deschamps, M., D. Le Bars, M. Yvon, and M.-P. ChapotChartier. 2004. Autolysis of Lactococcus lactis AM2 stimulates the formation of certain aroma compounds from amino acids in a cheese model. Int. Dairy J. 14:791-800.

Cromie, S. J., J. E. Giles, and J. R. Dulley. 1987. Effect of elevated ripening temperatures on the microflora of Cheddar cheese. J. Dairy Res. 54:69-76.

Drake, M. A., S. McIngvale, P. D. Gerard, K. R. Cadwallader, and G. V. Civille. 2001. Development of a descriptive language for Cheddar cheese. J. Food Sci. 66:1422-1427.

Drake, M. A., M. D. Yates, P. D. Gerard, C. M. Delahunty, E. M. Sheehan, R. P. Turnbull, and T. M. Dodds. 2005. Comparison of differences between lexicons for descriptive analysis of Cheddar cheese flavour in Ireland, New Zealand, and the United States of America. Int. Dairy J. 15:473-483.

Folkertsma, B., P. F. Fox, and P. L. H. McSweeney. 1996. Accelerated ripening of Cheddar cheese at elevated temperatures. Int. Dairy J. 6:1117-1134.

Fryer, T. F. 1969. Microflora of Cheddar cheese and its influence on cheese flavor. Dairy Sci. Abstr. 31:471-490.

Jackson, H. W., and M. E. Morgan. 1954. Identity and origin of the malty aroma substance from milk cultures of $S$. lactis var. maltigenes. J. Dairy Sci. 37:1316-1324.

Meilgaard, M. M., G. V. Civille, and B. T. Carr. 1999. Selection and training of panel members. Pages 174-176 in Sensory Evaluation Techniques, 3rd ed. CRC Press, Boca Raton, FL.

National Institute of Standards and Technology (NIST). 1992. NIST/ EPA/NIH Mass Spectral Library. NIST, Gaithersburg, MD.

Rijnen, L., A. Delacroix-Buchet, D. Demaizieres, J. Le Quere, J. Gripon, and M. Yvon. 1999. Inactivation of lactococcal aromatic aminotransferase prevents the formation of floral aroma compounds from aromatic amino acids in semi-hard cheese. Int. Dairy J. 9:877-885.

Rychlik, M., P. Schieberle, and W. Grosch. 1998. Compilation of thresholds, odor qualities, and retention indices of key food odorants. Deutsche Forschungsanstalt fur Lebensmittelchemie and Instiut fur Lebensmittelchemie der Technischen Universitat Munchen, Garching, Germany.

Sheldon, R. M., R. C. Lindsay, L. M. Libbey, and M. E. Morgan. 1971. Chemical nature of malty flavor and aroma produced by Streptococcus lactis var. maltigenes. Appl. Microbiol. 22:263-266.

Smit, B. A., J. E. van Hylckama Vlieg, W. J. Engels, L. Meijer, J. T. Wouters, and G. Smit. 2005. Identification, cloning, and characterization of a Lactococcus lactis branched-chain $\alpha$-keto acid decarboxylase involved in flavor formation. Appl. Environ. Microbiol. 71:303-311.

Stepaniak, L. 2004. Dairy enzymology. Int. J. Dairy Technol. 57:153-171.

Tanous, C., A. Kieronczyk, S. Helinck, E. Chambellon, and M. Yvon. 2002. Glutamate dehydrogenase activity: A major criterion for the selection of flavour-producing lactic acid bacteria strains. Antonie Van Leeuwenhoek 82:271-278. 
Tucker, J. S., and M. E. Morgan. 1967. Decarboxylation of $\alpha$-keto acids by Streptococcus lactis var. maltigenes. Appl. Microbiol. 15:694-700.

Urbach, G. 1995. Contribution of lactic acid bacteria to flavour compound formation in dairy products. Int. Dairy J. 5:877-903.

Urbach, G. 1997. The chemical and biochemical basis of cheese and milk aroma. Pages 253-298 in Microbiology and Biochemistry of Cheeses and Fermented Milk. B. A. Law, ed. Chapman and Hall, London, UK.

Van den Dool, H., and P. Kratz. 1963. A generalization of the retention index system including linear programmed gas liquid partition chromatography. J. Chromatogr. 11:463-471.
Weenen, H., and J. G. M. van der Ven. 2001. The formation of Strecker aldehydes. Pages 183-195 in Aroma Active Compounds in Foods; Chemistry and Sensory Properties. G. Takeoka, M. Guntert, and K. Engle, ed. Am. Chem. Soc., Washington, DC.

Young, N.D., M. A. Drake, K. Lopetcharat, and M. R. McDaniel. 2004. Preference mapping of Cheddar cheeses with varying maturity levels. 87:11-19.

Yvon, M., S. Berthelot, and J. Gripon. 1998. Adding $\alpha$-ketoglutarate to semi-hard cheese curd highly enhances the conversion of amino acids to aroma compounds. Int. Dairy J. 8:889-898.

Yvon, M., and L. Rijnen. 2001. Cheese flavor formation by amino acid catabolism. Int. Dairy J. 11:185-202. 